\title{
Creating sustainable value through food waste management: does retail customer value proposition matter?
}

by Huang, I.Y., Manning, L., Wood, V., James, K.L., Millington, A., Grigoriadis, V. and Ward, S.

Copyright, publisher and additional information: .This is the authors' accepted manuscript. The published version is available via Emerald.

Please refer to any applicable terms of use of the publisher

DOI link to the version of record on the publisher's site 


\section{British Food Journal}

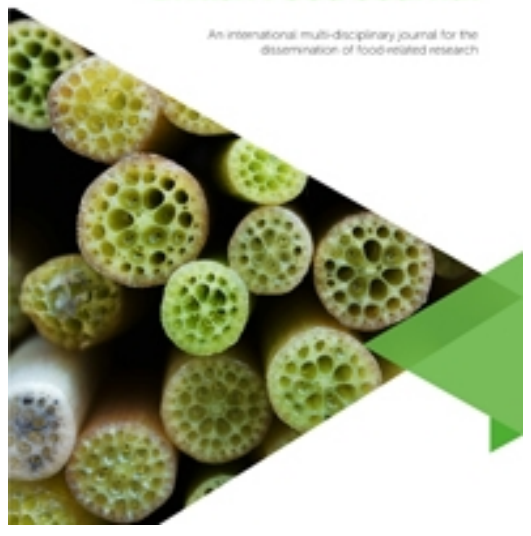

\section{Creating sustainable value through food waste management: Does retail customer value proposition matter?}

\begin{tabular}{|r|l|}
\hline Journal: & British Food Journal \\
\hline Manuscript ID & BFJ-06-2021-0693.R1 \\
\hline Manuscript Type: & Research Paper \\
\hline Keywords: & $\begin{array}{l}\text { retail sector, food waste, customer value proposition, value creation, } \\
\text { sustainable value }\end{array}$ \\
\hline
\end{tabular}

\section{SCHOLARONE Manuscripts}


1 Creating sustainable value through food waste management: Does retail customer value

2 proposition matter?

\section{Abstract}

4 Purpose - This research aims to explore retail managers' views on how food waste (FW) management activities contribute to sustainable value creation and how the customer value proposition (CVP) for a given food retailer interacts with their approaches to FW management.

7 Design/methodology/approach - A three-stage exploratory qualitative approach to data

8 collection and analysis was adopted, involving in-depth interviews with retail managers, 9 documentary analysis of multiple years of relevant corporate reports and email validation by seven major UK grocery retailers. Thematic content analysis supplemented by word similarity

11 cluster analysis, two-step cluster analysis and crisp-set qualitative comparative analysis were

12 undertaken.

13 Findings - FW management practices have been seen by retail managers to contribute to all 14 forms of sustainable value creation as waste reduction minimises environmental impact, saves costs and/or serves social needs whilst economic value creation lies at the heart of retail FW management. However, retail operations are also framed by CVP and size of a retailer that

17 enable or inhibit the adoption of certain FW management practices. Low-price retailers were more likely to adopt practices enabling them to save costs. Complicated cost-incurring

19 solutions to FW were more likely to be adopted by retailers associated with larger size, high 20 quality and a range of services.

21 Originality/value - This study is the first of its kind to empirically explore retail managers' perception of sustainable value creation through food waste management activities and to provide empirical evidence of the linkages between retail CVP and sustainable value creation

24 in the context of retail FW management. 
25 Keywords: retail sector, food waste, value creation, sustainable value, customer value 26 proposition (CVP)

27 

proposition matter?

\section{Introduction}

Food waste $(\mathrm{FW})$ is a wicked problem with boundary spanning causes but no unified definition and solutions (Närvänen et al., 2020). United Nations Environment Programme's (UNEP) most recent report estimates that a total of 931 million tonnes of food is wasted post farm gate each year, averaging $74 \mathrm{~kg}$ per capita globally (UNEP, 2021). FW in UNEP's report is defined as "food and the associated inedible parts removed from the human food supply chain" including food processing and manufacturing, food/grocery retail, food services and households (UNEP, 2021, p. 19). This study adopts Huang et al.'s (2021) definition which excludes inedible parts but includes "any food which has been produced for human consumption, but does not get consumed" (p.3). This includes FW that occurs at any stage in the process of food production, distribution and consumption. In this context, retailers can be viewed as critical intermediaries in the food supply chain (Närvänen et al., 2020), playing a pivotal role in reducing FW farm-to-fork (de Moraes et al., 2020).

Retail FW can arise from standards set by retailers, leading to rejection of food products that fail to meet quality requirements (Mena et al., 2014); food safety concerns (Gruber et al., 2016); the use of confusing date labelling (Aschemann-Witzel et al., 2016); problems with instore logistics and retailing format (Teller et al., 2018), and a lack of staff training (GoodmanSmith et al., 2020). There are multiple opportunities to reduce retail FW including improved efficiency and organisation (Teller et al., 2018), use of modern technology to deliver better stock management; and adherence to customer quality expectations (Goodman-Smith et al., 2020), and more autonomy for store managers (Rosenlund et al., 2020) so they can provide reactive solutions to reduce FW (Hermsdorf et al., 2017). Other options are take-back agreements with suppliers (Eriksson et al., 2017); repurposing or redistributing food in donation-based supply chains, recycling through animal feed (Goodman-Smith et al., 2020), 
nutrient or calorie recovery processes (e.g. anaerobic digestion) or ultimately sending to landfill (Filimonau and Gherbin, 2017).

Managing FW has the potential to integrate the creation of environmental value (Scherhaufer et al., 2018) and social value (Mirosa et al., 2016) with existing organisational processes of economic value creation (de Moraes et al., 2020) when considered against a backdrop of a growing global population, food poverty, food insecurity and climate change. However, most studies consider the retail waste management strategies adopted, via the waste hierarchy (Huang et al., 2021), in isolation from sustainable value creation and the CVP adopted by each food retailer and the mechanisms of value delivery at retail and/or supply chain level. There is, as a result, a paucity of research on how a food retailer's CVP might interact with the value creation activities associated with managing FW.

Value is a term constructed by individuals and communities as a combination of factors that revolve around cost and reward/benefit (Manning, 2015). Value can be described as a combination of utility value i.e. customers' perceptions of the product value and exchange value i.e. the economic value derived from organisational activities (Bowman and Ambrosini, 2000). The value construct of profit maximisation and shareholder benefit has been extended over time to consider stakeholder value or shared value (Porter and Kramer, 2011), i.e. creating sustainable value for society as a whole. In the context of retail FW management, Huang et al. (2021) present a conceptual framework to demonstrate how sustainable value is created through FW management. They propose an "economic value plus" approach to sustainable value creation with a nuanced perspective on economic value which includes three forms: perceived surplus value, exchange value and mitigation value. The model shows that effective management of FW by retailers can create at least one form of economic value plus environmental value and/or social value. As the concept is still emergent, there are gaps in the identification of the antecedent conditions of sustainable value creation (Foss and Saebi, 2018), 
and, in particular, a lack of understanding of how the organisation's existing CVP shapes and

80 frames the way sustainable value is created (Evans et al., 2017).

CVP is a poorly defined managerial concept which has often been used as an alternative for a business model (Payne et al., 2017), a component of a business model (Haas et al., 2019) or a retailing format (Yrjölä et al., 2014). Based on a systematic review of literature on retail business models, Rintamäki and Kirves (2017) identify four types of CVP in the retail context: economic value proposition (low price), emotional value proposition (customer experience), functional value proposition (solutions) and symbolic value proposition (meanings). Retail CVP can alternatively be described in terms of the offering i.e. assortment or range of products, price and service), customer experience (atmosphere) and shopping convenience encompassing opening hours, location, amenities and availability (Yrjölä et al., 2014; Haas, 2019). Retail CVP aligns with organisational capabilities and resources to promote competitive advantage (Rintamäki and Kirves, 2017) and the connection between value proposition and value creation and delivery is key in studies of business models. One common understanding is that value proposition reflects the target customer, their rationale for why they should purchase the organisational offering (product, service or combination of both) and an understanding of the interaction between price and perceived benefit (Payne et al., 2017). Customer value can be created via operational efficiency, operational effectiveness and customer lock-in as well as value being captured by the business itself and its partners (Sorescu et al., 2011).

However, a specific research gap exists in terms of how these interactions between business model components occurs (Wirtz, 2016; Haas, 2019), especially how retail CVP enables, or

100 conversely hampers opportunities for sustainable value creation. Cognisant of this lack of 101 empirical evidence and paucity of understanding of how the association between FW and sustainable value creation is perceived by retail managers, this paper aims to answer two interrelated central questions: 
1. What is retail managers' understanding of how sustainable values can be created through FW management?

2. How does the CVP of a given retailer interact with sustainable value creation through their FW management activities?

The context of this study is FW management by United Kingdom (UK) food retailers. As

110 it is a relatively concentrated sector dominated by nine big retailers, the UK food retail sector

111 is ideal to explore the interaction between CVP and sustainable value creation. Studies in the

112 UK have explored causes of retail FW (Mena et al., 2014), reporting of FW in sustainability

113 policies and reports (Bobe and Dragonmir, 2010; Jones et al., 2015), and the role of the third

114 sector in redistribution of retail food surplus (Alexander and Smaje, 2008). More recently,

115 studies have examined managerial attitudes towards FW issues and mitigation practices

116 reported by local store managers of the seven UK food retailers (Filimonau and Gherbin, 2017),

117 channels used to communicate FW issues to consumers (Young et al., 2018), adoption of best

118 practice to influence household FW reduction (WRAP 2019), and motivations driving UK

119 retailers' commitment to FW reduction (Swaffield et al., 2018). However, the level of adoption

120 of practices varies between retailers (Feedback, 2018). In the UK, a voluntary approach to FW

121 management practices has been enactioned (apart from the Landfill Directive) and all UK

122 retailers face nearly identical external pressures to manage FW. In such circumstances,

123 different responses may be determined by internal institutional contexts (Souza-Monteiro and

124 Hooker, 2017). The empirical research findings will enrich our understanding of the constraints

125 and conduciveness of key retail contextual factors such as CVP and size in managing FW and 126 creating value for shareholders and wider stakeholders.

\section{Methodology}

128

2.1 Research design 
The association between CVP and sustainable value creation is a nascent area with limited

130 empirical evidence (Haas, 2019). This study takes on an interpretive understanding of social

131 action using a qualitative exploratory approach (Bazeley and Jackson, 2013) and triangulation

132 with multiple data sources, a method commonly used in studies of challenging UK retail

133 settings with a small number of large competitors (Filimonau and Gherbin, 2017; Rosenlund

134 et al., 2020).

1352.2 Research context, sample selection and data collection

136 In the UK, there are 19 chain grocery retailers, nine of which are major players with market

137 share ranging from $4 \%$ to $25.8 \%$ (Mintel, 2019). The sales of the nine major food retailers

138 totalled $87 \%$ of the UK grocery market in 2019 (Mintel, 2019). Large retailers were chosen for

139 this study due to their more consistent corporate responsibility reporting (Souza-Monteiro and

140 Hooker, 2017), more clearly defined CVPs in terms of atmosphere, availability, price, quality,

141 product range and service provision, and their associated power to influence both upstream and

142 downstream FW practices.

143 The number of the food retailers in the UK is small and the challenges of obtaining

144 responses from retail managers have been well documented (Filimonau and Gherbin, 2017).

145 This study adopted a three-stage mixed method approach to data collection involving 146 triangulation of data sources (stage 1 and 2) and checking for discrepancies and requesting

147 clarification from retailers (stage 3 ) to ensure data validity. Similar approaches involving 148 documentary analysis and interviews has been used by other studies on retailers' FW (e.g.

149 Filimonau and Gherbin, 2017; Rosenlund et al., 2020). This study builds on previous work by

150 adding the third stage confirmation by retail managers of the data analysis results.

151 Stage-one of this study used individual face-to-face semi-structured interviews. Details of 152 how the responses were obtained in this study can be found in Appendix 1. Altogether, five 153 one-to-one interviews (representing four retailers) were conducted including three store 
managers and two corporate sustainability directors, with each lasting around 1.5 hours. They were all recorded and fully transcribed.

Due to the challenges of gaining responses from all top nine retailers to discuss FW issues, corporate reports downloaded from the websites of all nine major retailers in the UK. These reports included sustainability reports, corporate social responsibility reports, annual reports and/or strategic reports between 2013 and 2018 if available online (see Appendix 1 for details). All reports were initially collated in 2018 and were subjected to iterative thematic content analysis.

To enhance the content validity, stage 3 involved asking all nine retailers to confirm the thematic content analysis coding of the documentary evidence. FW management practices were listed separately in an excel file for each of the top nine retailers. Each practice was defined to avoid any misunderstanding. Findings were provided for each practice as 'yes' or 'no' for each retailer. Respondents were asked to provide an example if a practice had to be changed from a 'no' to a 'yes' to make sure claims were evidenced. An open-ended question was added for the respondent to provide further comments and explanations regarding why 'yes' or why 'no' to each practice. This excel file was emailed to the $\mathrm{CEO}$ and corporate sustainability director (if available) of each of the top nine retailers. After two reminders, seven responses were received (see Appendix 1). The final analysis was therefore based on the data from those seven retailers comprising of two private, two partnerships/cooperatives and three public companies. Some

174 retailers asked to be anonymised. Due to the small number of major retailers in the UK, it was

175 decided to keep all retailers anonymous. Of the seven retailers, two were small-sized (M3, and 176 P2), three were medium (D1, D2 and P1) and two were large (M1 and M2) based on their 177 annual sales per store outlet times market share in 2019 (Mintel, 2019). 
All transcriptions and corporate documents were imported and coded in NVivo which

180 allowed double checking and comparison. Thematic content analysis was carried out by at least two of the co-authors. This involved open coding of descriptive themes (read line by line), axial coding (categorising and recoding) and selective coding (refining on axial coding and identification of relationship) (Bazeley and Jackson, 2013). Each coder also checked their own reliability of coding by re-reading all data and recoding up to five times during the process. The validity of the coding of the FW management practices was also enhanced by the $3^{\text {rd }}$ stage verification from the retail managers.

187 Three thematic frameworks were used for content analysis: retail managers' understanding of sustainable value creation through FW management practices (Huang et al., 2021), the actual adoption of retail FW management practices (Huang et al., 2021) by the seven retailers and

190 CVP of the retailers (Rintamäki and Kirves, 2017).

The sustainable value creation framework conceptualised by Huang et al., (2021) in the context of FW management was used to code sustainable value creation as perceived by retail managers. To understand how economic, environmental and social value creation interact with each other and with five FW management hierarchy elements, a coding word similarity cluster analysis was conducted in NVivo.

Twenty-seven FW management practices were coded using the 5-level FW management

197 hierarchy (i.e. reduce/prevent, reuse, recycle, recover and dispose). Of the 27 practices, 15 were

198 universally reported by all retailers and 12 were reported by some of the seven retailers. The latter 12 practices were then subjected to a two-step cluster analysis to identify potential grouping trends. This suggested a three-cluster division which seemed to be linked to the CVP 201 of the retailers.

The CVP of the seven retailers are positioned based on the six key dimensions applied in Rintamäki and Kirves (2017): atmosphere, availability, price competitiveness, quality, 
assortment/range, and services. Two retailers (D1 and D2) were coded as predominantly low-

205 price based (discounters). Both stress low price being their core offering as one commented that "customers shop at our business because prices are low" (D1) and the other mentioned that "our main customer base is those who cannot afford to shop at other retailers" (D2). Two retailers (premium) were coded as high on atmosphere, quality and service (P1 and P2) as explained by one of the interviewees (P1) that "price is never far from customers minds. But I think they wouldn't shop with my shop or my company because of price. They would shop for other reasons. ... service, food quality, atmosphere. Those are the things that I would hear about most" (P1). P2 stated in their report that they offer "special and different, ... indulgent range, excitement and newness of products to delight customers". M1 and M2 were coded high on service, range and product availability as they aim for "ensuring customers can get what want, when they want it" (M1) and "a sustainable and secure supply of the everyday products our customers love (M2). M3 is a retailer which does not show very clear CVP, but coded high on service, a message repeated in their reports.

To identify the relationship between CVP and adoption of FW management practices, this study has taken a realist approach to understanding the causally relevant contexts (i.e. CVP and size) of retailers' FW management through identifying patterns and cross-case comparisons (Maxwell, 2012). The configurational method with crisp-set qualitative comparative analysis (QCA) populated by Ragin since 1987 was used (Ragin, 2014). All variables were coded as binary $(1,0)$ and analysed with fsQCA 3.1 (Ragin and Davey, 2016). This method is particularly suitable for exploring causal configurations with small sample sizes.

A key feature of QCA is its ability to explore multiple causal pathways (equifinality) and causal asymmetry (Fiss, 2011), which means that causes for the presence of an outcome may be different from causes leading to the negated outcome. This study explored the casual conditions (i.e, CVP components and firm size) for both presence (indicated by "1") and absence (indicated by "0") of the outcomes (i.e, FW management practices excluding those 
which were universally shared by all retailers). Absence in QCA of this study means 'low' in

231 condition. Based on the coding presented in Table $2 b$ and $2 c$, crisp-set QCA was conducted with CVP and size being used as contextual causal conditions for 24 outcomes (i.e. presence and negated of each of the $12 \mathrm{FW}$ management practices). The analysis does not assume a linear and additive effect in QCA and does not show statistical significance as in conventional correlation-based statistical models.

\section{Results and discussion}

\subsection{Perceived sustainable value creation through $F W$ management by grocery retailers}

238 Value creation and delivery ('how' value is created) can be broadly considered as activities in enhancing efficiency and customer effectiveness. As proposed by Huang et al. (2021), multiple values can be created through FW management by grocery retailers. Economic values can take the form of exchange value ("price paid for use value created"), perceived surplus value

242 ("customer's perception of value for money") and mitigation value ("associated cost reduction, compliance and licence-to-operate"). In FW management activities, either or both of environmental value and social value may be created alongside any or all of the three dimensions of economic value. Data from the seven retailers seems to support this framework very well. Creating economic value is clearly perceived as the core business case. For some retailers, this was in terms of achieving exchange value by selling cosmetic imperfect produce and/or products near expiry date at reduced price. The business case was also about achieving cost efficiency by reducing loss as explained by three retailers:

there is a clear business case as well for reducing $F W$... FW is a cost to our business, is a cost to our suppliers. ... It's about minimising that cost, but it's about growing top line sales, getting the mix right so the profitability of the company is good. M1

We are efficient in what we do, and FW plays a big part of that, that we do cut waste' D2.

My stock loss has gone from 1.8\% to .6\%, that's a cool half a million. M2. 
Cost savings were also achieved via reduced cost for raw materials; 'we're paying less because

it's class two [produce]' (D2) or through streamlining purchasing process:

258

259

260

261

262

263

264

265

266

267

268

269

270

271

272

273

274

275

276

277

278

279

280

281

282

283

284

285

286

287

So instead of a product being half a stage sitting in a Spanish pack case and sitting in a UK pack case and then goes to our DCs and stores, we've changed the way we work with suppliers so the products essentially go direct from Spain to our distribution centres and stores. And that cuts, two days, out of the journey from farm to store. MI

Perceived surplus value creation was well recognised by retailers, in terms of building consumer trust, improving goodwill and customer loyalty through helping consumers to reduce

FW and/or enhancing perceived value for money via price mark downs.

there's a huge opportunity if we can help customers reduce waste and save money. Research from WRAP shows, those customers, the current customer loyalty element there. And also again a financial-- a business case because according to WRAP's analysis half of that money saved is spent again in shops. And whether that's trading up or coming back to the same store, you know, there's a clear business case. M1.

[FW campaigns] go on social media nowadays, .... So I'm sure it does bring a commercial benefit along the way somewhere ... We get loads of positive goodwill from doing this. M2.

The retailers identified enhancing reputation as a significant source of value in FW management as shown below:

I'm saying that because of the heightened awareness and agenda of $F W$, there's additional value to be had by promoting what we're doing. ... because our customers want to see us doing it and we're doing it. So therefore we know from a reputational perspective there is value. DI

The third dimension of economic value, mitigation value creation, involves reducing costs for FW disposal and ensuring compliance with the Landfill Directive. All but P1 saw FW management as an opportunity to reduce such costs. D2 commented that "We currently measure avoided disposal cost and have seen a good saving from redistributing food." This was echoed by M3 who commented that "It costs more to send to AD [anaerobic digestion] than to redistribute." More explanations were provided by another manager:

... So we have invested in terms of segregating our FW in stores, which allows us to send more to $A D$, and certainly as a requirement for sending it to animal feed. We receive money for sending the product to animal feed, and that's the bit that varies 
depending on the commodity price for wheat. Obviously there's a cost for waste disposal, be that incineration with energy recovery or AD. M1

FW from landfill. As put forward by Respondent $1 \mathrm{M} 1$, “....anything that drives it up the waste

hierarchy reduces environmental impact" suggesting that all practices directing food away from landfill would create environmental benefits and the higher up the hierarchy, the more vegetables, reducing price to facilitate produce sell out in store, streamlining operational processes and using technology to minimise FW all demonstrated quantifiable evidence of sustainable value creation in that they not only created exchange value for the retailers but also generated environmental benefits due to the food staying in the food system for human consumption, hence offsetting the resources and carbon emissions incurred for extra food production.

Social value creation was perceived via practices at the higher level of the FW hierarchy, namely reduce and reuse. Some respondents identified more long-term social value than simply feeding people in need:

Its things like it goes to a breakfast club in the morning and for kids, and they have seen in the last 6 months a direct improvement in the children's attendance, academic performance, because they're getting fed in the morning by our excess waste food. ...we're directly affecting young children who perhaps weren't going to get a breakfast and they might end up having a better life because their academic performance is better. M2.

Thus, social value creation occurs through supporting individual farmers and the agri-

311 food industry in general through whole or glut crop purchase practices, and supporting people

312 in poverty through price reduction, or surplus food donation (Goodman-Smith et al., 2020).

313 More extensive exemplary quotes on how sustainable values can be created through the range

314 of FW management practices by the retailers can be found from Table 1 . The quotes were 
315 colour coded to highlight the economic, environmental and social value as perceived by the

316 retail managers.

\section{Take in Table 1}

Cluster analysis based on word similarity of the top-level codes of the sustainable values and the FW hierarchy was conducted in NVivo (Figure 1). The results showed that economic value in the forms of 'perceived surplus value' and 'exchange value' were clustered with 'reduce' whilst 'environmental value' and 'social value' with 'reuse'. 'Mitigation value' was clustered with 'waste disposal', and 'recover' and 'recycle' were clustered together.

323 Details of the correlation coefficient*1 ${ }^{1}$ of word similarity of the full range of codes can be found 324 in Appendix 2.

\section{Take in Figure 1}

This analysis provides strong evidence of the interactions between perceived

environmental and/or social values creation and economic value creation through managing FW. The next section looks at the similarities and differences in adoption of FW management practices by the retailers and whether a retailer's context such as CVP and size might explain

330 the different FW approaches adopted.

\subsection{FW management practices adopted by the UK retailers}

332 The results of the iterative analysis of the FW management practices by the seven retailers can

333 be found in Table 2. The categories used to organise the practices followed the waste hierarchy,

334 i.e. reduce, reuse, recycle, recover and dispose (Huang et al., 2021).

\section{Take in Table 2}

\footnotetext{
${ }^{1}$ This is generated in NVivo. No p value was generated unlike conventional statistical analysis.
} 
336 Unsurprisingly, due to the heavy promotion of the FW hierarchy by WRAP and FAO, there

337 were far more practices reported by retailers to reduce/prevent FW. No activities were reported

338 on disposal because landfill disposal has been discouraged as a result of the EU Landfill

339 Directive introduced in 2009. Of the 27 items listed in Table 2, 15 FW management practices

340 were commonly adopted, which fall into four categories: 1) reducing FW by making internal

341 operational changes to achieve better cost efficiency, 2) undertaking activities to influence

342 consumers to reduce FW, 3) surplus food redistribution by working with charities, and 4)

343 recycling by sending FW for anaerobic digestion. It could be argued that these four categories

344 of practices were low hanging fruits or easy wins for all retailers. Minimising/reducing FW

345 through internal changes such as improving packaging, forecasting, temperature control,

346 ordering or stock monitoring is closely related to cost reduction in a tight margin sector. These

347 themes concur with the findings of Cicatiello et al. (2020). As one of the respondents 348 commented: under food security and social equality headings. Although food donation has not been made a legal obligation in the UK, social pressures from charity organisations such as Fareshare have made food donation a must-do item for all retailers. Whilst this is a standing item in retail FW management practice, the amount of food donation could be improved (Goodman-Smith et al., 2020). WRAP (2019) suggested that only 17,500 tonnes out of 300,000 tonnes of retail FW was redistributed to people in 2018. If surplus food can be collected by charities, this was seen as a cheaper way of dealing with FW before the "use-by" date: "It is more expensive to send food to anaerobic digestion than to redistribute" $M 3$. 

redistribution of food compared to FW disposal. All major UK retailers have signed up to the

363 Courtauld Commitments ${ }^{2} 2025$ instigated and delivered by WRAP (2019). Helping households

to reduce FW through consumer food awareness campaigns, providing guidance on storage,

freezing and meal planning and cooking have been heavily promoted by WRAP with retailers.

Therefore, it is not unexpected to see that all retailers addressed this in their FW practices.

367 Retailers see food donation and FW campaigns as a way to win public trust, and this may translate into customer loyalty or perceived surplus value, a form of economic value.

Twelve actions were not universally adopted. Details of each action by retailer are shown in

Table $2 \mathrm{~b}$. Presence of the action is indicated by " 1 " and negated action indicated by " 0 ". As explained previously, the seven retailers differ in size and CVP (Table 2b and 2c). An SPSS two-step cluster analysis of the $12 \mathrm{FW}$ management practices generated three clusters with silhouette measure of cohesion and separation being just over .5, an indication of good cluster quality (Appendix 3). This analysis showed that D1 and D2 are in a distinct cluster, and M1 and $\mathrm{M} 2$ in cluster 2 and $\mathrm{M} 3, \mathrm{P} 1$ and P3 in cluster 3. Cluster 1 retailers (D1 and D2) are both medium-sized and have clearly adopted a low-cost low-price CVP with medium sized store outlets and limited product range and availability. Retailers in this cluster seemed to have focused on FW prevention and reduction through interrelated actions of selling cosmetically

380 imperfect produce, relaxing cosmetic standards and whole crop purchasing. They also reported 381 reviewing stock and cutting product range. Their low-cost, simplicity strategy also influenced their decision for not making BOGOF offers. Practices not adopted by this cluster included offering alternative packaging formats for small households, surplus food deposit banks for

\footnotetext{
${ }^{2}$ A series of voluntary agreements aiming to improve resource efficiency and reduce the carbon and wider environmental impact of the UK grocery sector, launched in 2005. For details, visit https://archive.wrap.org.uk/food-drink/business-food-waste/history-courtauld.
} 
customers instore, in-store reprocessing, pre-processed surplus food and recycling surplus food for animal feed. Such non-adoptions were associated with their CVP of not focusing on providing additional services and very tight cost control which underpins their low-price offering as commented by one of the respondents.

In summary, the low-price low-cost based economic value proposition meant that in some ways this cluster's retail CVP was conducive to food waste control and was adaptive depending on the situation. They were able to prevent food waste effectively as part of their business model but also chose to ignore solutions which may increase their cost of operations. Cluster two retailers (M1 and M2) were large scale retailers with CVP aiming to provide a one-stop food shopping experience with a wide range of customer offering including big product assortment and services such as fresh butcher counters and in-store cafes. They tried to compete on all fronts across the consumer base with multiple CVPs, but their offering cannot compete on price with cluster 1 and on quality with the premium retailers within cluster 3 . The most distinct defining elements of CVP for this cluster were: range, availability, services. This

398 cluster have adopted more FW management practices than the other two groups. It may be argued that there was a bigger scope and demand for actions to be taken as their CVPs may have led to a higher volume of FW generation, particularly due to bigger product range, availability and promotion activities. What distinguished this cluster most from cluster 1

402 retailers were embedded FW practices such as changing packaging to cater for small 403 households, providing in-store surplus food deposit bank for customers, in-store redistribution 404 (e.g. 'free fruits for kids'), in-store processing (especially if they had a customer or staff café) and processing surplus or wonky food. These activities were directly linked to either their service proposition or their offering of pre-processed food. This is also the only group recycling

407 FW as animal feed. This could be linked to the scale of operation as the retailers could afford, 408 and need, to sort FW in order to meet legal obligations. 

within the group than the previous two groups. M3 seemed to be a 'drifter' with no clear CVP 411 apart from service (convenience). This may be due to the regional structural nature of the

412 retailer with the CVP being driven in a disseminated rather than centralised approach. P1 and 413 P2 provide a quality-based offering associated with higher social status/identity with defining 414 CVP elements offering service, quality, and atmosphere. P1 provided in-store surplus food 415 deposit banks for their customers and in-store surplus food redistribution whilst P2 saw this as incompatible with their store atmosphere. In addition, P1 and P2 differed in that P1 offered an essential product line and operated in-store cafés. This meant that P1 were able to sell slightly imperfect produce in their essential product line and had the option to reuse surplus food in their store café. Both P1 and P2 provide high quality pre-prepared foods to their customers and therefore predominantly reprocess surplus or wonky food from their suppliers in their supply chain, rather than sell in-store. Relaxing cosmetic standards for the normal product line, whole crop purchasing and selling past "best before" products were seen as incompatible with their CVP of high quality by both P1 and P2 (see Goodman-Smith et al., 2020). High quality offering to social status/identity focused customers affects both retailers in their promotion and product size offering as explained by the managers:

It matches with the demographics of not only my shop but also the changing demographics of customers. If they're aging and there's more single household[s], there was a bit of the packaging, but the biggest feeling I sensed from customers was about quantity. (P1)

We work carefully on portion control and work to ensure that we sell equal amounts of smaller size options $(P 2)$

Regarding BOGOF, according to the P1 manager, this model was incompatible with

434 CVP. Addressing the impact of promotions on retail FW is an important reduction strategy (de

435 Moraes et al., 2020), but cutting product range was not seen as compatible with their current 
437 the results show that offering of premium pre-prepared food products, high level of services

438 and shopping atmosphere may have acted as barriers to adopting some FW management 439 practices, meaning the retailers has to focus strategically on others if they wanted to reduce $440 \quad \mathrm{FW}$.

\subsection{Do a retailer's CVP and size matter in FW management?}

To understand how the above clustering of retailers based on their FW management practices were linked to the causal context of CVP and size of the retailers, crisp-set QCA was carried out. The causal pathways to the presence and negated FW management practice outcomes are shown in Table 3. Only parsimonious ${ }^{3}$ solutions are presented which shows the core conditions in terms of retailer's size and CVP for each of the $12 \mathrm{FW}$ management practices (either presence or negated).

\section{Take in Table 3}

All but one retailer (P2) sell imperfect product (also known as 'wonky' fruit and vegetables). Two core conditions led to this practice being not high on quality and atmosphere (M3) or not high on quality and atmosphere and not small (D1, D2, M1, M2) or medium size (P1). However, D1 and D2 marketed those products alongside their standard line as a Class 2 products whilst the others marketed them with labels of "perfectly imperfect" (M1) or "a little less than perfect" (P1). P2 was the only retailer that did not sell imperfect produce with core conditions being small and being high on atmosphere and quality in their CVP as commented by a store manager from P1 that said selling 'wonky veg' does not align with their marketing positioning of selling excellent produce. However, four retailers (D1, D2, M1, M2) showed a coherent set of actions underpinning their ability to sell 'wonky F\&V'. They were able to broaden their specifications because quality attributes such as being visually perfect were not 
460 a distinct CVP for those retailers. They also practiced whole crop purchase, underpinned by 461 the core condition of not being high on 'quality' and 'not being small' (P1). One of the retailers 462 explained that whole crop purchase enabled them to negotiate a low price with the suppliers. 463 M3, P1 and P2 did not practice whole crop purchase with the core condition being identified 464 as not competing on price and not being large retailers.

Five retailers (M1, M2, M3, P1 and P2) reported changing packaging for small households, underpinned by their CVP of offering high level of service and not competing on price. This is the opposite D1 and D2 which did not make this change for the reason that they were competing on price but not on service. No consistent solutions were generated for selling past 'best before' products for D1, D2, M1 and M2. M3 reported positively on this item, which was explained by their position being small and not competing on quality. P1 and P2 reported negatively on this because they compete on quality of products.

D1, D2 and M3 reported cutting product range so choice and guaranteed availability of a given product were not part of the proposition. P1 and P2 have not cut product range as their range is already more limited. No consistent solutions were generated for M1 which reported cutting range and M2 which did not. for consumer FW in the home (Filimonau and Gherbin, 2017), no core CVP conditions were identified for four retailers (M1, M2, M3, P2) who have removed BOGOF. But D1, D2 and P2 reported that BOGOF was never part of their offering for shared attributes, they do not normally have high level of stocks for cost control (D1 and D2) or high quality sits within their CVP (P2).

Turning to reuse/recycle of surplus food, five practices were reported by two to four retailers each. Three retailers (M2, M3 and P1) reported having in-store surplus food deposit bank for customers to donate. M2 and M3 shared core attributes of offering good service but 
not competing on store atmosphere, whilst $\mathrm{M} 2$ and $\mathrm{P} 1$ shared the attributes of offering good service and not being small. D1 and D2 did not provide this 'surplus food deposit' with core conditions being low on service and a low cost strategy. A D2 manager commented that "our store format and procedures do not currently allow us to do this". P2 also did not provide this service for the core condition of being small and high on store atmosphere. M2 did not appear in the solution. Another type of food donation was in-store redistribution to colleagues and free food for customers. M1 and M2 both reported to have practiced this. Core conditions for this shared practice were not competing on quality but on service and being large retailers as explained by one of the managers that "food not taken by charities is offered to colleagues through our 'colleague shops' which have been rolled out to all stores" (M1). The other five retailers did not practice this form of donation. D2 explained "our focus is on redistributing to charitable organisations".

In terms of surplus food reprocessing in store, no consistent solutions were generated for M1 and M2. P1 practiced this with the core condition being providing good service whilst, not competing on range and not small. D1, D2, M3 and P2 did not practice this with core condition being not competing on availability and product range. Not having staff canteens was given as a main reason for nonadopting by D2. However, four retailers reported reprocessing surplus or wonky food in their factories as pre-prepared food with M1 and M2 supported by the core condition of competing on availability and P1 and P2 with core condition of high quality. This is particularly highlighted in P2's report, perhaps to compensate for not selling wonky veg in store. D1, D2 and M3, not competing on quality and range, confirmed they did not practice this action. Finally, recycling surplus food as animal feed has been reported by two retailers (M1 and M2) with core conditions of being large and competing on range (which potentially could mean high stock and as a result higher waste warranting this practice) as not being large was the core condition for the other five retailers who did not follow 510 the practice. One of the managers explained that size does matter and they "don't possess the 
511 correct licence to supply animal feed in a commercial sense and currently this is cost-

512 prohibitive (D2)". D1 manager also commented about size and CVP related reasons that

513 "linking to our business model being a very efficient business, as soon as you bring [legal]

514 complexities into it, it makes it almost impossible for us to do".

\section{4. Conclusion and theoretical implications}

516 This research sought to address the current paucity of understanding of how sustainable

517 value creation is achieved via retail FW management and how different retail context such as

518 size and CVP might interact with sustainable value creation activities associated with FW management practices in the context of increasing environmental regulations and stakeholder pressures. There are three key findings in this study.

Firstly, it is clear from this study that FW management practices at all levels have been seen by retailer managers to contribute to all forms of sustainable value creation as waste reduction minimises environmental impact, saves costs and/or serves social needs. In particular, 'reduce' has been strongly associated with the creation of two forms of economic value: exchange value and perceived surplus value, 'reuse' more strongly associated with creation of social value and environmental value, and 'waste disposal' with mitigation value. Previously, only a conceptual framework of integration of FW management and sustainable value creation has been proposed by Huang et al., (2021). This finding provides the first empirical evidence of retail managers' perception of sustainable value creation achieved by FW management and the nuances of the three forms of economic value creation associated with FW management activities.

Secondly, the findings confirmed previous evidence showing that UK retailers have made great progress in minimising FW being sent for landfill (WRAP, 2019) and concurred

534 with previous studies that UK food retailers may be influenced by external societal pressures to reduce FW and also to derive associated economic value (Filimonau and Gherbin, 2017; 
536 Young et al., 2018; Swaffield et al., 2018) which are related to 25 commonly shared practices.

537 FW management practices such as making changes to raise consumer awareness and help 538 consumer to reduce waste have been a constant theme of WRAP's communication with 539 retailers (WRAP, 2019). Recommendations by WRAP to make efficiency enhancing changes

540 seemed to have been well received by the retailers too. Food donation via charities and sending

541 food waste to $\mathrm{AD}$ rather than to landfill were universally practiced. However, this study has

542 not explored the tensions between the third sector and the retailers as reported by Alexander 543 and Smaje, 2008).

Thirdly, the causal paths generated by csQCA and the two-step cluster analysis showed

545 that CVP and size of a given retailer do matter in explaining most of the differences and

546 similarities of the seven retailers' adoption of specific FW management practices. Low-price

547 retailers were more likely to adopt practices enabling them to save costs and reduce FW at the

548 same time. Complicated cost-incurring solutions to FW (e.g reprocessing, adopting a range of

549 SKUs) were more likely to be adopted by retailers associated with larger size, high quality and

550 a range of services. This finding extends prior work on understanding retailers' CVP

551 (Rintamäki and Kirva, 2017) and motivators of retail FW management (Swaffield et al., 2018;

552 Goodman-Smith et al., 2020) by showing how the food retailers' current CVP frames and shapes different FW practices and drives sustainable value creation, providing insight into how

554 businesses can create sustainable value through enhancing their operational efficiency and 555 effectiveness.

\section{5. Managerial implications and limitations}

This research has implications for management practices in retail stores, and also gives insight into how business models may need to evolve in the future to meet societal, environmental and economic pressure to reduce FW. There are clear management trade-offs highlighted in the findings of this research for retailers offering more choices, wider services, 
convenience and so forth. These business models are inherently more wasteful. This requires

562 food retailers to consider how they retain or restructure their CVP and associated business models to assure their competitive positioning whilst also delivering to their customers' and wider stakeholders' needs and aspirations.

Tackling FW is one of the effective ways of mitigating greenhouse gas (GHG) emissions and supporting people in need (UNEP, 2021). For policy makers, two key issues highlighted in this research are related to food donation and repurposing food waste for animal feed. Surplus food donation is voluntary in the UK. Whilst there has been an increase of food donated largely to charities, only $12.7 \%$ of retail edible food waste has been redistributed to people and about 9\% sent for animal feed (WRAP, 2021). The respondents of this study saw both as a cost incurring operation rather than cost saving. To encourage retail business behavioural change, more policy level incentives as those introduced in France could be considered.

The limitations of this study are that firstly no direct observations were conducted. There is the potential for inbuilt bias of self-reporting, however the three-stage approach has been developed to seek to mitigate this. Secondly, only seven UK food retailers were included in this study. Although three CVP cluster groups were identified, it would be ideal if this approach could be widened to other countries, particularly in France and in Italy as noted by Filimonau and Gherbin (2017) where food donation has been enforced. Thirdly, the interpretation of the

580 links between CVP, retailer size and FW management practices is not based on quantitative causal inference. There are also many other firm-specific factors and decision-making processes (e.g. leadership) which might help to explain the differences in value creation activities. Fourthly, future research could extend this study to examine how the actual measurable performance of FW reduction can be linked to the CVP of food retailers as more and more retailers are pressured to report FW data. Finally, the linkage between CVP and 
sustainable value creation is an emerging field of study and more research could be undertaken

587 in other sectors.

588

589

590

591

592

593

594

595

596

597

598

599

600

601

602

603

604

605

606

607

608

609

610

\section{References}

Alexander, C. and Smaje, C. (2008), "Surplus retail food redistribution: An analysis of a third sector model", Resources, Conservation and Recycling, Vol. 52 No. 11, pp. 1290-1298.

Aschemann-Witzel, J., Hooge, I. d. and Normann, A. (2016), "Consumer-related food waste: Role of food marketing and retailers and potential for action", Journal of International Food \& Agribusiness Marketing, Vol. 28 No. 3, pp. 271-285.

Bazeley, P. and Jackson, K. (2013), Qualitative data analysis with NVivo, Sage Publications Limited.

Bobe, C.-M. and Dragomir Voicu, D. (2010), "The sustainability policy of five leading European retailers ", Accounting \& Management Information Systems, Vol. 9 No. 2, pp. 268-283.

Bowman, C. and Ambrosini, V. (2000), "Value creation versus value capture: Towards a coherent definition of value in strategy", British Journal of Management, Vol. 11 No. 1, pp. 1-15.

Cicatiello, C., Blasi, E., Giordano, C., Martella, A. and Franco, S. (2020), "“If only I could decide": Opinions of food category managers on in-store food waste", Sustainability, Vol. 12 No. 20, pp. 8592.

de Moraes, C. C., de Oliveira Costa, F. H., Pereira, C. R., da Silva, A. L. and Delai, I. (2020), "Retail food waste: Mapping causes and reduction practices", Journal of Cleaner Production, Vol. 256, pp. 120124.

Eriksson, M., Ghosh, R., Mattsson, L. and Ismatov, A. (2017), "Take-back agreements in the perspective of food waste generation at the supplier-retailer interface", Resources, Conservation and Recycling, Vol. 122, pp. 83-93. 
611 Evans, S., Vladimirova, D., Holgado, M., Van, F., Yang, M. Y., Silva, E. A. and Barlow, C. Y. (2017), "Business model innovation for sustainability: Towards a unified perspective for creation of sustainable business models", Business Strategy and the Environment, Vol. 26 No. 5, pp. 597-608.

Feedback (2018), The food waste scorecard: An assessment of supermarket action to address food waste, available at: https://feedbackglobal.Org/wp-content/uploads/2018/06/ supermarket-scorecard_136_fv-1.Pdf.

Filimonau, V. and Gherbin, A. (2017), "An exploratory study of food waste management practices in the uk grocery retail sector", Journal of Cleaner Production, Vol. 167 No., pp. 1184-1194.

Fiss, P. C. (2011), "Building better causal theories: A fuzzy set approach to typologies in organization research", Academy of Management Journal, Vol. 54 No. 2, pp. 393-420.

Foss, N. J. and Saebi, T. (2018), "Business models and business model innovation: Between wicked and paradigmatic problems", Long Range Planning, Vol. 51 No. 1, pp. 9-21.

Goodman-Smith, F., Mirosa, M. and Skeaff, S. (2020), "A mixed-methods study of retail food waste in New Zealand", Food Policy, Vol. 92, pp. 101845.

Gruber, V., Holweg, C. and Teller, C. (2016), "What a waste! Exploring the human reality of food waste from the store manager's perspective", Journal of Public Policy \& Marketing, Vol. 35 No. 1, pp. 3-25.

Haas, Y. (2019), "Developing a generic retail business model - a qualitative comparative study", International Journal of Retail \& Distribution Management, Vol. 47 No. 10, pp. 1029-1056.

Hermsdorf, D., Rombach, M. and Bitsch, V. (2017), "Food waste reduction practices in 
635 Huang, I. Y., Manning, L., James, K. L., Grigoriadis, V., Millington, A., Wood, V. and Ward,

636

637

638

639

640

641

642

643

644

645

646

647

648

649

650

651

652

653

654

655

656

657

658

659

S. (2021), "Food waste management: A review of retailers' business practices and their implications for sustainable value", Journal of Cleaner Production, Vol. 285, pp.125484.

Jones, P., Comfort, D. and Hillier, D. (2015), "Sustainability and the UK's leading retailers", Market-Tržište, Vol. 27 No. 1, pp. 93-111.

Manning, L. (2015), "Determining value in the food supply chain", British Food Journal, Vol. 117 No.11, pp. 2649-2663.

Maxwell, J. A. (2012), "The importance of qualitative research for causal explanation in education", Qualitative Inquiry, Vol. 18 No. 8, pp. 655-661.

Mena, C., Terry, L. A., Williams, A. and Ellram, L. (2014), "Causes of waste across multi-tier supply networks: Cases in the UK food sector", International Journal of Production Economics, Vol. 152, pp. 144-158.

Mintel (2019), Supermarkets - UK, November 2019. Mintel Group, reports.mintel.com.

Mirosa, M., Mainvil, L., Horne, H. and Mangan-Walker, E. (2016), "The social value of rescuing food, nourishing communities", British Food Journal, Vol. 118 No. 12, pp. 3044-3058.

Närvänen, E., Mesiranta, N., Mattila, M. and Heikkinen, A. (2020), Food waste management: Solving the wicked problems, Springer.

Payne, A., Frow, P. and Eggert, A. (2017), "The customer value proposition: Evolution, development, and application in marketing", Journal of the Academy of Marketing Science, Vol. 45 No. 4, pp. 467-489.

Porter, M. and Kramer, M. R. (2011), "Creating shared value", Harvard business review, January-February, pp. 62-77.

Ragin, C. C. (2014), The comparative method: Moving beyond qualitative and quantitative strategies, Univ of California Press. 
660 Ragin, C. C. and Davey, S. (2016), Fuzzy-Set/Qualitative Comparative Analysis 3.0. Irvine, California: Department of Sociology, University of California.

Rintamäki, T. and Kirves, K. (2017), "From perceptions to propositions: Profiling customer value across retail contexts", Journal of Retailing and Consumer Services, Vol. 37, pp. $159-167$.

Rosenlund, J., Nyblom, Å., Matschke Ekholm, H. and Sörme, L. (2020), "The emergence of 666 food waste as an issue in Swedish retail", British Food Journal, Vol. 122 No. 11, pp.

Scherhaufer, S., Moates, G., Hartikainen, H., Waldron, K. and Obersteiner, G. (2018), "Environmental impacts of food waste in Europe", Waste Management, Vol. 77 No., pp. 98-113.

Sorescu, A., Frambach, R. T., Singh, J., Rangaswamy, A. and Bridges, C. (2011), "Innovations in retail business models", Journal of Retailing, Vol. 87 No.1, pp. S3-S16.

Souza-Monteiro, D. and Hooker, N. (2017), "Comparing UK food retailers corporate social responsibility strategies", British Food Journal, Vol. 119 No. 3, pp. 658-675.

Swaffield, J., Evans, D. and Welch, D. (2018), "Profit, reputation and 'doing the right thing': Convention theory and the problem of food waste in the UK retail sector", Geoforum, Vol. 89, pp. 43-51.

Teller, C., Holweg, C., Reiner, G. and Kotzab, H. (2018), "Retail store operations and food waste", Journal of Cleaner Production, Vol. 185, pp. 981-997.

United Nations Environment Programme (UNEP) (2021), Food Waste Index Report 2021. Nairobi, available at: https://www.unep.org/resources/report/unep-food-waste-indexreport-2021.

Wirtz, B. W., Pistoia, A., Ullrich, S. and Gottel, V. (2016), "Business models: Origin, 
686 WRAP (2019), Food waste reduction roadmap progress report, available at: $687 \quad$ www.wrap.org.uk/food-waste-reduction-roadmap.

688 WRAP (2021), Food surplus and waste in the UK - key facts, available at:

689 https://wrap.org.uk/sites/default/files/2021-10/food-\%20surplus-and-\%20waste-in-

$690 \quad$ the-\%20uk-key-facts-oct-21.pdf

691 Young, C. W., Russell, S. V., Robinson, C. A. and Chintakayala, P. K. (2018), "Sustainable 692 retailing - influencing consumer behaviour on food waste", Business Strategy and the 693 Environment, Vol. 27 No. 1, pp. 1-15.

694 Yrjölä, M., Saarijärvi, H. and Nummela, H. (2018), "The value propositions of multi-, cross-, 695 and omni-channel retailing", International Journal of Retail \& Distribution Management, $696 \quad$ Vol. 46 No. 11/12, pp. 1133-1152.

697 


\section{Table 1 Perceived sustainable value creation through food waste management practices}

\begin{tabular}{|c|c|c|c|c|c|c|}
\hline \multirow{2}{*}{$\begin{array}{l}\text { Food waste } \\
\text { management } \\
\text { practices }\end{array}$} & \multirow[b]{2}{*}{ Exemplar quotes } & \multicolumn{3}{|c|}{$\begin{array}{l}\text { Economic value } \\
\text { creation }\end{array}$} & \multirow{2}{*}{ 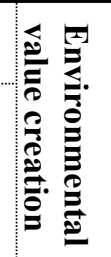 } & \multirow{2}{*}{ 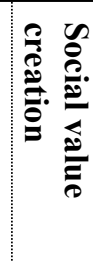 } \\
\hline & & 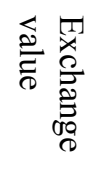 & 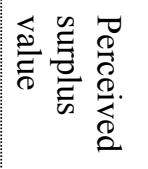 & 党: & & \\
\hline $\begin{array}{l}\text { Selling cosmetic } \\
\text { imperfect } \\
\text { produce }\end{array}$ & $\begin{array}{l}\text { We are now selling on average over } 500 \text { tonnes of 'Wonky } \\
\text { Veg' to over } 500,000 \text { customers every week across all of } \\
\text { our stores and online. Our Wonky Veg range helps to } \\
\text { reduce unnecessary food waste on farm. M2 }\end{array}$ & (E) & & & (e) & (S) \\
\hline $\begin{array}{l}\text { Reducing price } \\
\text { for near expiry } \\
\text { dates }\end{array}$ & $\begin{array}{l}\text { My stock loss has gone from } 1.8 \% \text { to } .6 \% \text {, that's a cool } \\
\text { half a million. M2. We reduce the amount of waste that we } \\
\text { were producing. Again that fits into the food poverty by } \\
\text { keeping cost down for our customers. D1 }\end{array}$ & (E) & (E) & (E) & (e) & (S) \\
\hline $\begin{array}{l}\text { Making internal } \\
\text { operational } \\
\text { changes to } \\
\text { minimise food } \\
\text { waste }\end{array}$ & $\begin{array}{l}\text { If you think there's } x \text { number of shops and they're all } \\
\text { potentially throwing away } 10 \text { grand a week. So if they can } \\
\text { turn the dial down by } 5 \text { or } 6 \% \text { that just drops straight off. } \\
\text {. To my mind, what will really help is the tie; that } \\
\text { environmental or ethical concerns can be tied in with } \\
\text { profitability. M2 }\end{array}$ & (E) & & (E) & (e) & (S) \\
\hline $\begin{array}{l}\text { Whole crop } \\
\text { purchase }\end{array}$ & $\begin{array}{l}\text { We saved } 70,000 \mathrm{~kg} \text { of potatoes from waste by buying up } \\
\text { the whole crop when the grower had a glut. D } 2 \\
\text { I think helping the farmers, the industry and the agriculture } \\
\text { in the UK is important. Respondent } 2 \text { of M1 }\end{array}$ & (E) & & & (e) & (S) \\
\hline $\begin{array}{l}\text { Helping } \\
\text { suppliers to } \\
\text { control food } \\
\text { waste }\end{array}$ & $\begin{array}{l}\text { Our suppliers have seen less waste and less associated } \\
\text { environmental impacts, which has allowed them to control } \\
\text { cost. D2 Food waste is a cost to our business, is a cost to } \\
\text { our suppliers Respondent } 1 \text { of M1 }\end{array}$ & (E) & & (E) & (e) & (S) \\
\hline $\begin{array}{l}\text { Helping } \\
\text { consumers to } \\
\text { reduce food } \\
\text { waste }\end{array}$ & $\begin{array}{l}\text { There's a huge opportunity if we can help customers } \\
\text { reduce waste and save money. } \\
\text { We have applied new food waste messaging on our entire } \\
\text { fruit, veg and bakery lines. This messaging enforces the } \\
\text { value of food and provide customers with tips to reduce } \\
\text { food waste. D1 } \\
\text { And because food waste is an issue that customers, } \\
\text { colleagues really care about then it's a clear opportunity to } \\
\text { build trust. Respondent } 1 \text { of M1. }\end{array}$ & & (E) & & (e) & (S) \\
\hline Food donations & $\begin{array}{l}\ldots \text { you're reducing waste and helping people in need in } \\
\text { this case so it's really positive and beneficial. Society feels } \\
\text { very strongly about it. Respondent } 1 \text { of M1. } \\
\text { We currently measure avoided disposal cost and have seen } \\
\text { a good saving from redistributing food (over } £ 37,000 \text { in } \\
2018 \text { )." D2 }\end{array}$ & & (E) & (E) & (e) & (S) \\
\hline $\begin{array}{l}\text { Recycle for } \\
\text { animal feeds }\end{array}$ & $\begin{array}{l}\text { We receive money for sending the product to animal feed, } \\
\text { and that's the bit that varies depending on the commodity } \\
\text { price for wheat. Obviously there's a cost for waste } \\
\text { disposal, be that incineration with energy recovery or AD. } \\
\text { In terms of it staying in the food system and offsetting } \\
\text { other feeds which have significant environmental impacts. } \\
\text {.. I think anything that drives it up the waste hierarchy } \\
\text { reduces environmental impact. Respondent } 1 \text { of M1 }\end{array}$ & (E) & (E) & (E) & (e) & \\
\hline $\begin{array}{l}\text { Diverting food } \\
\text { waste from } \\
\text { landfill and } \\
\text { other disposal }\end{array}$ & $\begin{array}{l}\text { Food waste reduction results in lower disposal fees. } \\
\text { It's cheaper for us to send to anaerobic digestion than } \\
\text { it is to send to landfill. AD has reduced the cost of } \\
\text { our waste. D1 }\end{array}$ & & & (E) & (e) & \\
\hline
\end{tabular}

Colour Notations: (E)- Economic value; (e)- environmental value; (S) - social value 
Table 2. Food waste management practices reported by 7 UK large retailers

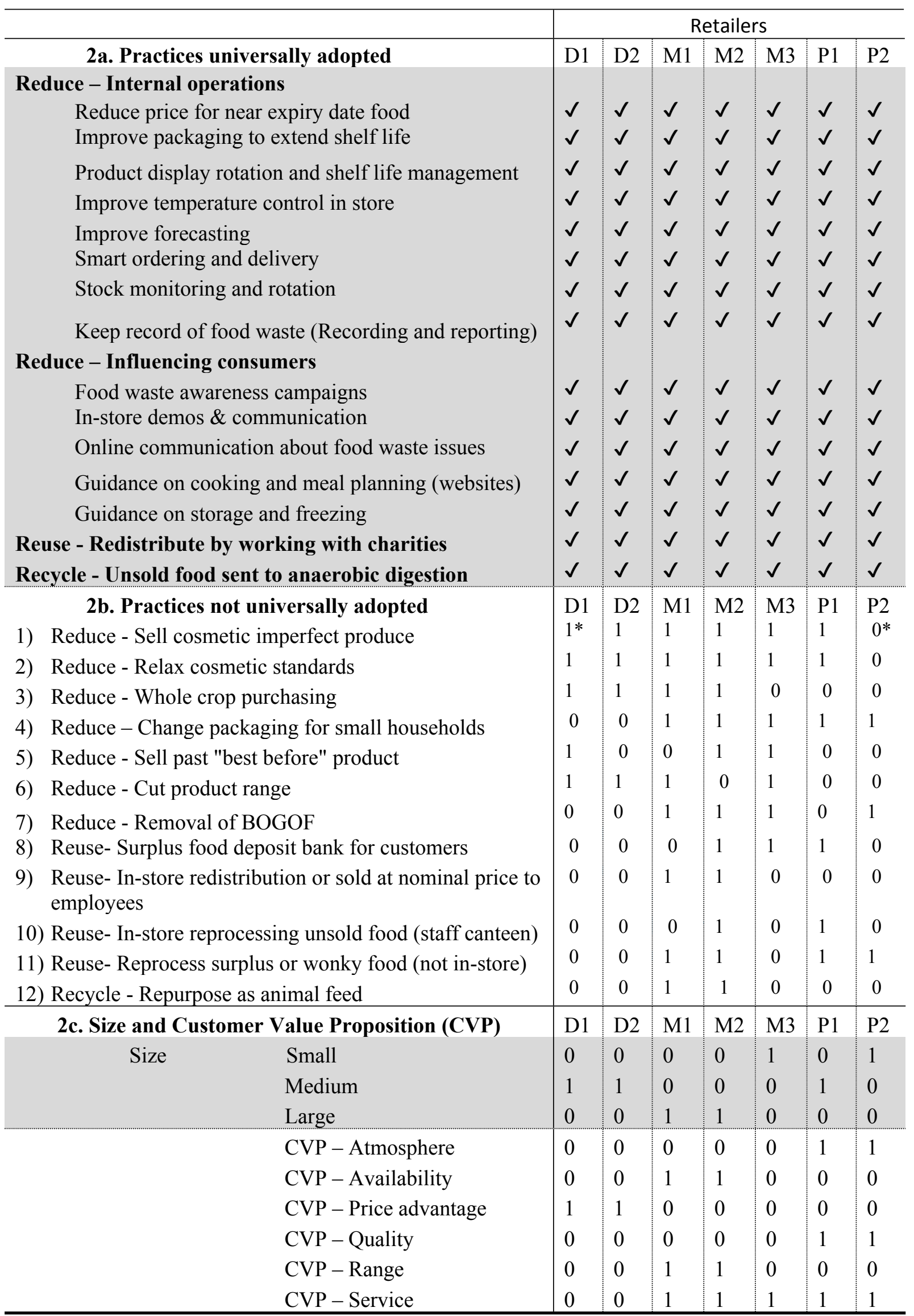

*Notation: $1=$ presence $($ or high); $0=$ absence (or Low) 
Table 3. Configurations of different food waste management practiced by UK retailers on components of CVP and size of retailer

\begin{tabular}{|c|c|c|c|c|c|c|c|c|c|c|c|c|}
\hline \multirow[b]{2}{*}{$\begin{array}{l}\text { FW } \\
\text { management } \\
\text { practices }\end{array}$} & \multirow[b]{2}{*}{$\begin{array}{l}\text { Solution } \\
\text { coverage } \\
\text { (solution } \\
\text { consistency) }\end{array}$} & \multirow[b]{2}{*}{ Cases } & \multicolumn{9}{|c|}{ Causal conditions (CVP \& Size) } & \multirow[b]{2}{*}{ Exemplary quotes } \\
\hline & & & 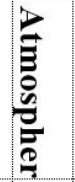 & 党: & 象. & 里 & 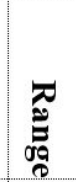 & $\frac{\ln }{3}$ & 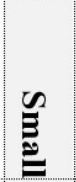 & 光 & 蒫 & \\
\hline \multirow{3}{*}{$\begin{array}{l}\text { Sell cosmetic } \\
\text { imperfect } \\
\text { produce (SCIP) }\end{array}$} & \multirow{3}{*}{$1(1)$} & $\begin{array}{l}\mathrm{D} 1, \mathrm{D} 2 \\
\mathrm{M} 1, \mathrm{M} 2\end{array}$ & $\otimes$ & & & $\otimes$ & & & $\otimes$ & & & $\begin{array}{l}\text { We have introduced Class } 2 \text { products in a selection of our Everyday } \\
\text { Essentials lines. It runs alongside a standard pack with Class } 1 \text { fruit(D2) } \\
\text { we launched our Perfectly Imperfect range of 'wonky' fruit and vegetables, } \\
\text { which ...maximise the amount of produce we can sell in store, and give } \\
\text { our customers great products at low prices. This enables us to take more } \\
\text { of the crop than ever before and reduce food waste on farms. (M1) }\end{array}$ \\
\hline & & M3 & $\otimes$ & & & $\otimes$ & & & & & & No comments \\
\hline & & $\mathrm{P} 1$ & & & & & & & & & & $\begin{array}{l}\text { so during the year we launched a new range of class two vegetables named } \\
\text { 'a little less than perfect' where price per kilo is cheaper than our lowest } \\
\text { essential range. (P1, corporate) }\end{array}$ \\
\hline$\sim \mathrm{SCIP}$ & $1(1)$ & $\mathrm{P} 2$ & & & & & & & & & & No comments \\
\hline \multirow[t]{3}{*}{$\begin{array}{l}\text { Relax cosmetic } \\
\text { standards (RCS) }\end{array}$} & \multirow[t]{3}{*}{$1(1)$} & $\begin{array}{l}\mathrm{D} 1, \mathrm{D} 2 \\
\mathrm{M} 1, \mathrm{M} 2\end{array}$ & & & & $\otimes$ & & & $\otimes$ & & & $\begin{array}{l}\text { Working with our suppliers we regularly review our standard product } \\
\text { specifications to ensure they are realistic and fair. D1 } \\
\ldots \text { makes potato chips from those potatoes that fall outside of our } \\
\text { specifications. And those are sold in our store. (M1) }\end{array}$ \\
\hline & & M3 & & & & $\otimes$ & & & & & & No comments \\
\hline & & $\mathrm{P} 1$ & & & & & & & $\otimes$ & & & No comments \\
\hline$\sim \mathrm{RCS}$ & $1(1)$ & $\mathrm{P} 2$ & & & & & & & & & & $\begin{array}{l}\text { How can a retailer who wants to be known for selling fresh, excellent } \\
\text { produce, how can it be selling wonky veg? (P1) }\end{array}$ \\
\hline $\begin{array}{l}\text { Whole crop } \\
\text { purchase (WCP) }\end{array}$ & $1(1)$ & $\begin{array}{l}\mathrm{D} 1, \mathrm{D} 2 \\
\mathrm{M} 1, \mathrm{M} 2\end{array}$ & & & & $\otimes$ & & & $\otimes$ & & & $\begin{array}{l}\text { We've got arrangements with suppliers where we've formally contractually } \\
\text { agreed to take the whole crop. (D1) } \\
\text { Wonky pack supports whole crop procurement for our grower base. (D2) } \\
\text { We buy direct from farmers and have the ability to process whole animals } \\
\text { or crops, therefore we utilise more of what we buy with less wastage. (M2) }\end{array}$ \\
\hline$\sim \mathrm{WCP}$ & $1(1)$ & $\mathrm{M} 3, \mathrm{P} 1, \mathrm{P} 2$ & & & $\otimes$ & & & & & & $\otimes$ & We want to buy as much of our farmers' crop as possible. (P1) \\
\hline
\end{tabular}

$\sim=$ negated outcome

= Core presence of the causal condition; $\bigotimes=$ Core absence of the causal condition 
Table 3. Configurations of different food waste management practiced by UK retailers on components of CVP and size of retailer (Continued)

\begin{tabular}{|c|c|c|c|c|c|c|c|c|c|c|c|c|}
\hline \multirow[b]{2}{*}{$\begin{array}{l}\text { Food waste } \\
\text { management } \\
\text { practices }\end{array}$} & \multirow[b]{2}{*}{$\begin{array}{l}\text { Solution } \\
\text { coverage } \\
\text { (Solution } \\
\text { consistency) }\end{array}$} & \multirow[b]{2}{*}{ Cases } & \multicolumn{9}{|c|}{ Causal conditions (CVP \& Size) } & \multirow[b]{2}{*}{ Exemplary quotes } \\
\hline & & & $\frac{0}{0}$ & 宸 & 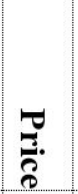 & O를 & 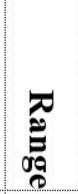 & 象 & $\stackrel{\mathscr{E}}{\mathscr{E}}$ & 宽 & 象 & \\
\hline $\begin{array}{l}\text { Change } \\
\text { packaging for } \\
\text { small households } \\
\text { (CPSP) }\end{array}$ & $1(1)$ & $\begin{array}{l}\text { M1, M2, } \\
\text { M3, P1, } \\
\text { P2 }\end{array}$ & & & $\otimes$ & & & 0 & & & & $\begin{array}{l}\text { We have redeveloped our two portion chicken fillets packaging with a } \\
\text { separate compartment for each fillet, so that customers can 'eat one and } \\
\text { keep one'. (M1) } \\
\text { We work carefully on portion control and work to ensure that we sell equal } \\
\text { amounts of smaller size options (P2) }\end{array}$ \\
\hline$\sim \mathrm{CPSP}$ & $1(1)$ & D1, D2 & & & 0 & & & $\otimes$ & & & & No comments \\
\hline $\begin{array}{l}\text { Selling past "best } \\
\text { before" products }\end{array}$ & $0.333(1)$ & M3 & & & & $\otimes$ & & & 0 & & & No comments \\
\hline$\sim$ SPBBP & $0.5(1)$ & $\mathrm{P} 1, \mathrm{P} 2$ & & & & O & & & & & & No comments \\
\hline $\begin{array}{l}\text { Cutting product } \\
\text { range (CPR) }\end{array}$ & $0.75(1)$ & $\begin{array}{l}\text { D1, D2, } \\
\text { M3 }\end{array}$ & & $\otimes$ & & $\otimes$ & $\otimes$ & & & & & $\begin{array}{l}\text { Wastage on product lines is monitored daily by store teams and orders } \\
\text { adjusted appropriately. (D1) We removed over } 100,000 \text { of these } \\
\text { underperforming store/product combinations from the stores' ordering } \\
\text { system in } 2013 \text {, saving } 1,093 \text { tonnes of food waste, equating to } £ 12.8 \mathrm{~m} \text { in } \\
\text { cost savings. (M3) }\end{array}$ \\
\hline$\sim \mathrm{CPR}$ & $0.6667(1)$ & P1, P2 & & & & 0 & & & & & & No comments \\
\hline $\begin{array}{l}\text { Removed } \\
\text { BOGOF offers }\end{array}$ & $1(1)$ & $\begin{array}{l}\text { M1, M2, } \\
\text { M3, P2 }\end{array}$ & & & & & & & & $\otimes$ & & $\begin{array}{l}\text { That whole ethos of more is best isn't anymore. It's about understanding } \\
\text { what actually when customers want to use them and -- I remember we did } \\
\text { a promotion on iceberg lettuces, it was buy two, get two free. (M1) }\end{array}$ \\
\hline$\sim$ BOGOF & $1(1)$ & $\begin{array}{l}\text { D1, D2, } \\
\text { P1 }\end{array}$ & & $\otimes$ & & & $\otimes$ & & & ○ & & $\begin{array}{l}\text { XX does not, and never has, offered BOGOFs. (D2) } \\
\text { Never part of the offering (P1) }\end{array}$ \\
\hline
\end{tabular}

$\sim=$ negated outcome; $=$ Core presence of the causal condition; $\otimes$ = Core absence of the causal condition 
Table 3. Configurations of different food waste management practiced by UK retailers on components of CVP and size of retailer (Continued)

\begin{tabular}{|c|c|c|c|c|c|c|c|c|c|c|c|c|}
\hline \multirow[b]{2}{*}{$\begin{array}{l}\text { Food waste } \\
\text { management } \\
\text { practices }\end{array}$} & \multirow[b]{2}{*}{$\begin{array}{l}\text { Solution } \\
\text { coverage } \\
\text { (Solution } \\
\text { consistency) }\end{array}$} & \multirow[b]{2}{*}{ Cases } & \multicolumn{9}{|c|}{ Causal Conditions (CVP \& Size) } & \multirow[b]{2}{*}{ Exemplary quotes } \\
\hline & & & $\begin{array}{l}2 \\
E \\
0 \\
0 \\
0 \\
0 \\
0 \\
0 \\
0\end{array}$ & 党 & कृ. & 里 & 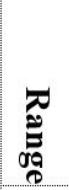 & $\frac{\infty}{2}$ & $\stackrel{\mathscr{N}}{\stackrel{\mathscr{N}}{\Xi}}$ & $\sum^{2}$ & gृ: & \\
\hline \multirow{2}{*}{$\begin{array}{l}\text { Surplus food } \\
\text { deposit bank in } \\
\text { store (SFBiS) }\end{array}$} & \multirow[t]{2}{*}{$0.66667(1)$} & $\mathrm{M} 2, \mathrm{M} 3$ & $\otimes$ & & & & & & & & & $\begin{array}{l}\text { Where possible, we allow space for front of store food banks so customers } \\
\text { can donate goods. (M2) }\end{array}$ \\
\hline & & $\mathrm{M} 2, \mathrm{P} 1$ & & & & & & & $\otimes$ & & & [We use]Trussell Trust donation banks (P1) \\
\hline \multirow{2}{*}{$\sim$ SFBiS } & \multirow[t]{2}{*}{$0.75(1)$} & D1, D2 & & & O & & & $\otimes$ & & & & Our store format and procedures do not currently allow us to do this. (D2) \\
\hline & & P2 & & & & & & & & & & No comments \\
\hline $\begin{array}{l}\text { In-store } \\
\text { redistribution } \\
\text { (ISRD) }\end{array}$ & $1(1)$ & $\mathrm{M} 1, \mathrm{M} 2$ & & & & $\otimes$ & & & & & & $\begin{array}{l}\text { Food not taken by charities is offered to colleagues through our 'colleague } \\
\text { shops' which have been rolled out to all stores. (M1) }\end{array}$ \\
\hline$\sim$ ISRD & $1(1)$ & $\begin{array}{l}\mathrm{D} 1, \mathrm{D} 2 \\
\mathrm{M} 3, \mathrm{P} 1 \\
\mathrm{P} 2\end{array}$ & & & & & $\otimes$ & & & & $\otimes$ & $\begin{array}{l}\text { Our focus is on redistributing to charitable organisations. (D2) } \\
\text { Now even that will be replaced by ensuring it's all sold at markdown to } \\
\text { customers or colleagues (P2) }\end{array}$ \\
\hline $\begin{array}{l}\text { In-store } \\
\text { reprocessing (IR) }\end{array}$ & $0.5(1)$ & $\mathrm{P} 1$ & & & & & $\otimes$ & & $\otimes$ & & & No comments \\
\hline$\sim \mathrm{IR}$ & $0.8(1)$ & $\begin{array}{l}\mathrm{D} 1, \mathrm{D} 2 \\
\mathrm{M} 3, \mathrm{P} 2\end{array}$ & & $\otimes$ & & & $\otimes$ & & & & $\otimes$ & We don't have staff canteens. We don't have colleague shops. (D2) \\
\hline
\end{tabular}

$\sim=$ negated outcome; $\mathrm{O}=$ Core presence of the causal condition; $\otimes$ = Core absence of the causal condition 
Table 3. Configurations of different food waste management practiced by UK retailers on components of CVP and size of retailer (Continued)

\begin{tabular}{|c|c|c|c|c|c|c|c|c|c|c|c|c|}
\hline \multirow[b]{2}{*}{$\begin{array}{l}\text { Food waste } \\
\text { management } \\
\text { practices }\end{array}$} & \multirow{2}{*}{$\begin{array}{l}\text { Solution } \\
\text { coverage } \\
\text { (Solution } \\
\text { consistency) }\end{array}$} & \multirow[b]{2}{*}{ Cases } & \multicolumn{9}{|c|}{ Causal conditions (CVP \& Size) } & \multirow[b]{2}{*}{ Exemplary quotes } \\
\hline & & & 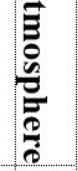 & :. & בְ. & O̊: & 餢 & 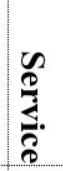 & $\mathscr{n}$ & 光 & 票 & \\
\hline \multirow{2}{*}{$\begin{array}{l}\text { Reprocessing } \\
\text { surplus food prior } \\
\text { to store }\end{array}$} & $1(1)$ & $\mathrm{M} 1, \mathrm{M} 2$ & & 0 & & & & & & & & $\begin{array}{l}\text { Washed carrots and onions not used as Wonky Veg go into different } \\
\text { streams such as our factories to be processed as pre-prepared food. (M2) }\end{array}$ \\
\hline & & $\mathrm{P} 1, \mathrm{P} 2$ & & & & O & & & & & & $\begin{array}{l}\text { We have worked with our suppliers to effectively use surplus e.g. wonky } \\
\text { parsnips are used in our parsnip mash. This is at a factory levels where } \\
\text { factories innovate using surplus food. (P2) }\end{array}$ \\
\hline $\begin{array}{l}\sim \text { Reprocessing } \\
\text { surplus food }\end{array}$ & $1(1)$ & $\begin{array}{l}\text { D1, D2, } \\
\text { M3 }\end{array}$ & & & & $\otimes$ & $\otimes$ & & & & & No comments \\
\hline $\begin{array}{l}\text { Repurpose as } \\
\text { animal feed }\end{array}$ & $1(0.5)$ & M1, M2 & & & & & 0 & & & & 0 & $\begin{array}{l}\text { So, we have invested in terms of segregating our food waste in stores. We } \\
\text { receive money for sending the product to animal feed, and that's the bit } \\
\text { that varies depending on the commodity price for wheat. Obviously, } \\
\text { there's a cost for waste disposal, be that incineration with energy recovery } \\
\text { or AD. (M1) }\end{array}$ \\
\hline $\begin{array}{l}\sim \text { Repurpose as } \\
\text { animal feed }\end{array}$ & $0.8333(1)$ & $\begin{array}{l}\text { D1, D2, } \\
\text { M3, P1, } \\
\text { P2 }\end{array}$ & & & & & & & & & $\otimes$ & $\begin{array}{l}\text { We don't possess the correct licence to supply animal feed in a commercial } \\
\text { sense and currently this is cost-prohibitive. (D2) }\end{array}$ \\
\hline
\end{tabular}

$\sim=$ negated outcome; $\mathbf{Q}$ = Core presence of the causal condition; $\otimes=$ Corle absence of the causal condition 


\section{Items clustered by word similarity}

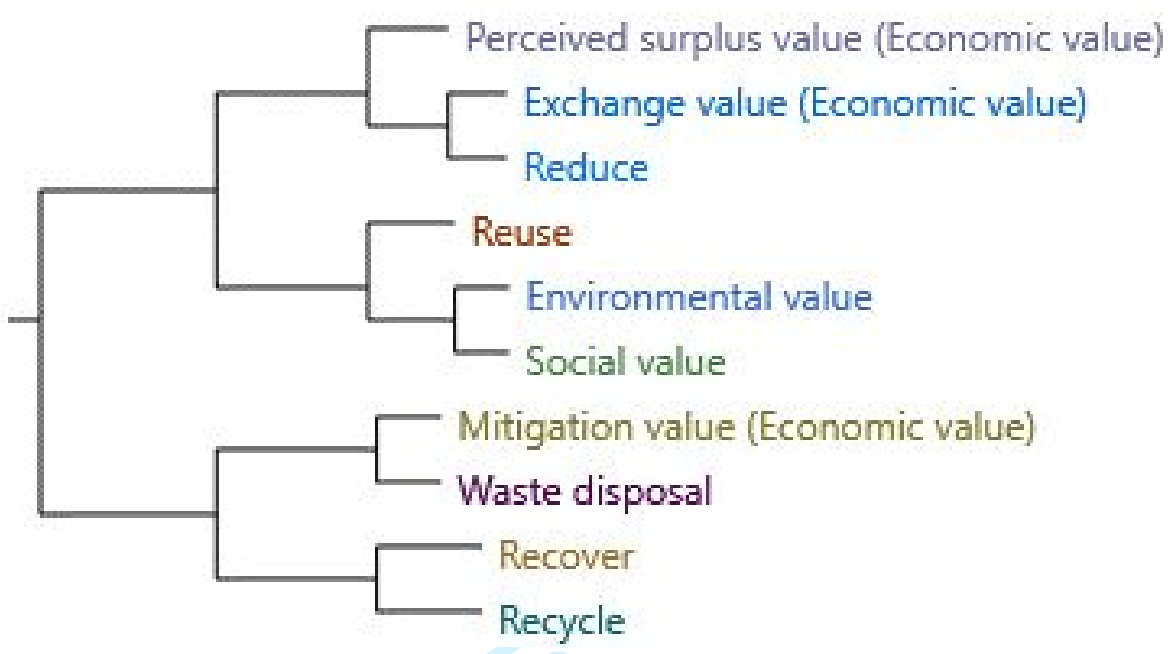

Figure 1 Clustering summary based on word similarity of codes of FW management and dimensions of sustainable value creation in NVivo 
1 Creating sustainable value through food waste management: Does retail customer value

2 proposition matter?

3

4 Supplementary material for review

5

6 Appendix 1. Retailer coding and grey literature analysed in the study associated with 7 each retailer.

\begin{tabular}{|c|c|c|c|c|c|c|}
\hline \multirow{2}{*}{$\begin{array}{c}\text { Retailer } \\
\text { code }\end{array}$} & \multirow{2}{*}{ Stage $1 *$} & \multicolumn{4}{|c|}{ Stage 2 - Reports analysed } & \multirow{2}{*}{$\begin{array}{l}\begin{array}{l}\text { Stage } 3 \text { email } \\
\text { confirmation }\end{array} \\
\begin{array}{l}\text { With further } \\
\text { comments }\end{array}\end{array}$} \\
\hline & & $\begin{array}{l}\text { Annual } \\
\text { report }\end{array}$ & $\begin{array}{l}\text { Corporate } \\
\text { Social } \\
\text { Responsibility } \\
\text { report }\end{array}$ & $\begin{array}{l}\text { Sustainability } \\
\text { report }\end{array}$ & $\begin{array}{l}\text { Strategic } \\
\text { Report }\end{array}$ & \\
\hline D1 & Corporate director & & 2016 & 2016 & & Yes \\
\hline D2 & No interview & 2016 & 2015,2016 & 2015,2017 & & Yes \\
\hline M1 & $\begin{array}{l}\text { Corporate director } \\
\text { (Respondent 1) } \\
\text { Store manager } \\
\text { (Respondent 2) }\end{array}$ & $2013-18$ & 2015,2016 & 2013,2014 & $2015-18$ & No \\
\hline M2 & Store manager & $2013-17$ & $2013-17$ & & $2013-17$ & Yes \\
\hline M3 & No interview & 2013-17 & & $2013-17$ & & Yes \\
\hline P1 & Store manager, & 2013-18 & 2015,2017 & $2013,2014,2016$ & & Yes \\
\hline $\mathrm{P} 2$ & No interview & 2014-18 & & $2013-18$ & & Yes \\
\hline
\end{tabular}

8

9 *For Stage 1, initial efforts were made in this study to contact both store managers and key

10 contacts at retailer headquarters. Apart from the extremely busy work schedules of store

11 managers, it soon became clear that store managers needed approval from their corporate

12 headquarters to be interviewed and some deferred to the corporate sustainability director or 13 equivalent. This prompted the researchers to contact the corporate sustainability director or 14 CEOs directly. All top UK retailers $(n=9)$ were contacted by both email and phone calls.

15 Follow-up emails were also sent and four retailers agreed to be interviewed. The four retailers 16 include one premium retailer (P1), two multi-orientated retailers (M1; M2) and one 17 discounter (D1).

18 


\section{Appendix 2: Clustering summary based on word similarity of codes of FW management and dimensions of sustainable value creation in NVivo}

\begin{tabular}{|c|c|c|}
\hline Code A & Code B & Pearson correlation coefficient \\
\hline Perceived surplus value (Economic value)* & Exchange value (Economic value) & 0.707207 \\
\hline Mitigation value (Economic value) & Exchange value (Economic value) & 0.483519 \\
\hline Perceived surplus value (Economic value) & Mitigation value (Economic value) & 0.351939 \\
\hline Perceived surplus value (Economic value)* & Reduce & 0.81049 \\
\hline Perceived surplus value (Economic value) & Recycle & 0.46253 \\
\hline Perceived surplus value (Economic value) & Reuse & 0.262532 \\
\hline Perceived surplus value (Economic value) & Recover & 0.227927 \\
\hline Perceived surplus value (Economic value) & Waste disposal & 0.20836 \\
\hline Exchange value (Economic value)* & Reduce & 0.838087 \\
\hline Exchange value (Economic value) & Recycle & 0.422829 \\
\hline Exchange value (Economic value) & Waste disposal & 0.35798 \\
\hline Exchange value (Economic value) & Reuse & 0.281913 \\
\hline Exchange value (Economic value) & Recover & 0.249683 \\
\hline Reduce & Environmental value & 0.820967 \\
\hline Reuse* & Environmental value & 0.667556 \\
\hline Recycle & Environmental value & 0.568493 \\
\hline Recover & Environmental value & 0.439719 \\
\hline Waste disposal & Environmental value & 0.351501 \\
\hline Reuse* & Social value & 0.843101 \\
\hline Reduce & Social value & 0.585784 \\
\hline Recycle & Social value & 0.315402 \\
\hline Recover & Social value & 0.240727 \\
\hline Waste disposal & Social value & 0.209955 \\
\hline Social value* & Environmental value & 0.863657 \\
\hline Waste disposal* & Mitigation value (Economic value) & 0.803462 \\
\hline Recycle & Mitigation value (Economic value) & 0.493932 \\
\hline Recover & Mitigation value (Economic value) & 0.379119 \\
\hline Reduce & Mitigation value (Economic value) & 0.344194 \\
\hline Reuse & Mitigation value (Economic value) & 0.21431 \\
\hline Recycle* & Recover & 0.550581 \\
\hline Exchange value (Economic value) & Environmental value & 0.7888 \\
\hline Perceived surplus value (Economic value) & Environmental value & 0.754003 \\
\hline Mitigation value (Economic value) & Environmental value & 0.523968 \\
\hline Exchange value (Economic value) & Social value & 0.569095 \\
\hline Perceived surplus value (Economic value) & Social value & 0.551589 \\
\hline Mitigation value (Economic value) & Social value & 0.336091 \\
\hline
\end{tabular}

\section{*shown in the cluster diagram in Figure 1.}


29

30 Appendix 3. Two-step cluster analysis based on the $12 \mathrm{FW}$ practices not universally practiced

\section{Model Summary}

\begin{tabular}{|l|l|}
\hline Algorithm & TwoStep \\
\hline Inputs & 12 \\
\hline Clusters & 3 \\
\hline
\end{tabular}

\section{Cluster Quality}

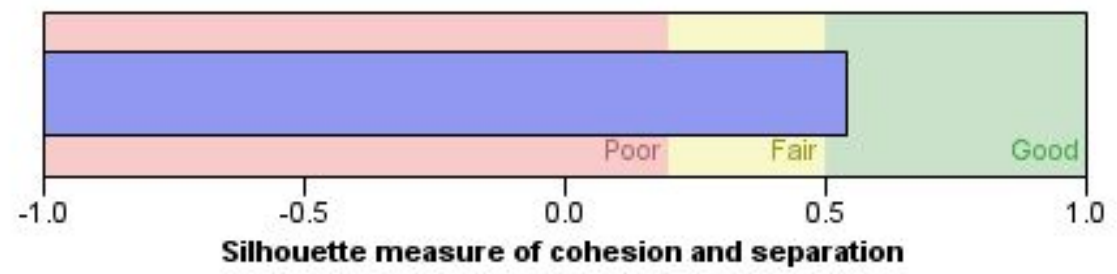

\begin{tabular}{r|l|l|l|l|l|l|l|} 
Cluster number & 1 & 1 & 2 & 2 & 3 & 3 & 3 \\
\hline Cluster membership & D1 & D2 & M1 & M2 & M3 & P1 & P2
\end{tabular}

